\title{
Idiopathic subarachnoid hemorrhage: a multicentre series of 220 patients
}

\author{
R. Sarabia; A. Lagares'; J.A. Fernández-Alén'; F. Arikan²; J. Vilalta²; J. Ibáñez³ A. Maillo4; A. Gabarros ${ }^{5}$; J. \\ Domínguez $^{6}$; A. Horcajadas ; F. Ballenilla ${ }^{8}$; G. Rodríguez-Boto9; J.L. Llacer ${ }^{10}$; I. Arrese ${ }^{11}$; A. de la Lama ${ }^{12}$; D. \\ Santamarta $^{13}$; P. Delgado ${ }^{14}$ and M. ${ }^{a}$ F. Muñoz \\ Hospital Clínico Universitario Valladolid. Hospital 12 de Octubre Madrid ${ }^{1}$. Hospital Vall d'Hebron Barcelona². Hospital Son Dureta Palma \\ de Mallorca ${ }^{3}$. Hospital Clínico Universitario Salamanca ${ }^{4}$. Hospital Bellvitge Barcelona ${ }^{5}$. Hospital Virgen de la Candelaria Tenerife ${ }^{6}$. Hospital \\ Virgen de las Nieves Granada ${ }^{7}$. Hospital General Alicante ${ }^{8}$. Hospital Clínico San Carlos Madrid ${ }^{9}$. Hospital Ribera Alcira ${ }^{10}$. Hospital Donosti San \\ Sebastián ${ }^{11}$. Hospital Xeral Vigo ${ }^{12}$. Hospital Virgen Blanca León ${ }^{13}$. Hospital General Yagüe Burgos ${ }^{14}$.
}

Summary

Background. The Spanish neurosurgical society created a multicentre data base on spontaneous SAH to analyze the real problematic of this disease in our country. This paper focuses on the group of patients with idiopathic SAH (ISAH).

Methods. 16 participant hospitals collect their spontaneous SAH cases in a common data base shared in the internet through a secured web page, considering clinical, radiological, evolution and outcome variables. The 220 ISAH cases collected from November 2004 to November 2007 were statistically analyzed as a whole and divided into 3 subgroups depending on the CT blood pattern (aneurysmal, perimesencephalic, or normal).

Results. The 220 ISAH patients constitute $19 \%$ of all 1149 spontaneous $\mathrm{SAH}$ collected in the study period. In $46,8 \%$ of ISAH the blood CT pattern was aneurysmal, which was related to older age, worse clinical condition, higher Fisher grade, more hydrocephalus and worse outcome, compared to perimesencephalic $(42,7 \%)$ or normal CT $(10,4 \%)$ pattern. Once surpassed the acute phase, outcome of ISAH patients is similarly good in all 3 ISAH subgroups, significantly better as a whole compared to aneurysmal SAH patients. The only variable related to outcome in ISAH after a logistic regression analysis was the admission clinical grade.

Conclusions. ISAH percentage of spontaneous SAH is diminishing in Spain. Classification of ISAH cases depending on the blood $\mathrm{CT}$ pattern is important to differentiate higher risk groups although complications are not negligible in any of the ISAH subgroups. Neurological status on admission is the single most valuable prognostic factor for outcome in ISAH patients.

KEY WORDS: Spontaneous subarachnoid hemorrhage. Idiopathic subarachnoid hemorrhage. Risk factors. CT blood pattern. Outcome. Multicentre study.

Recibido: 22-06-10. Aceptado: 17-07-10.
Hemorragia subaracnoidea idiopática: resultados de una serie multicéntrica de 220 pacientes

Resumen

Propósito. El grupo de trabajo de Patología Vascular de la SENEC desarrolló y mantiene abierta una base de datos multicéntrica que recoge los casos de hemorragia subaracnoidea espontánea. Con esta base se pretende analizar la problemática real que representa esta patología en nuestro medio. Este trabajo se centra en el estudio del grupo de pacientes de la base que presentaron HSA idiopática o de origen no aclarado (HSAI).

Materiales y métodos. La base de datos recoge los casos de HSA espontánea de 16 hospitales españoles a través de una página Web compartida en Internet de forma segura. Se consideran variables epidemiológicas, clínicas y radiológicas, así como la aparición de complicaciones y la evolución de los pacientes. Entre Noviembre de 2004 y Noviembre de 2007 se recogieron 220 pacientes con HSA idiopática. Este grupo se ha analizado estadísticamente de forma global y subdividido en 3 grupos de acuerdo con el patrón TC de sangrado inicial (de tipo aneurismático, perimesencefálico o TC normal).

Resultados. Los 220 pacientes con HSAI representan el $19 \%$ del total de 1.149 pacientes con HSA recogidos en la base de datos en el mismo periodo.

El 46,8\% de los casos de HSAI presentaron patrón de sangrado aneurismático en $\mathrm{TC}$, hecho que se correlacionó con mayor edad, peor condición clínica al ingreso, mayor grado Fisher de sangrado, más frecuencia de hidrocefalia y peor evolución, comparados con los casos de HSAI con sangrado en TC del tipo perimesencefálico $(42,7 \%)$ o con TC normal $(10,4 \%)$.

Una vez superada la fase aguda, e independientemente del tipo de sangrado inicial, la evolución de los pacientes con HSAI es globalmente buena $\mathbf{y}$ significativamente mejor que la de los pacientes con HSA aneurismática. La única variable con valor pronóstico en los casos de HSAI, tras realizar un análisis de 
regresión logística, es el grado clínico al ingreso.

Conclusiones. La proporción de casos de HSAI entre las HSA espontáneas está disminuyendo en nuestro país. Debe mantenerse la clasificación de los casos de HSAI según el patrón de sangrado inicial en TC porque permite diferenciar grupos de mayor riesgo entre estos pacientes, aunque pueden aparecer complicaciones graves en todos los tipos de HSAI. La situación clínica al ingreso es el factor individual pronóstico más importante en la evolución de estos pacientes.

PALABRAS CLAVE: Hemorragia subaracnoidea espontánea. HSA idiopática. Factores de riesgo. Patrón de sangrado en TC. Pronóstico. Estudio multicéntrico.

\section{Introduction}

Spontaneous SAH is still nowadays a serious illness whose incidence and mortality haven't changed in the past 10 years $^{31,63}$. Approximately $15 \%$ of SAH patients have no angiographically demonstrable source of bleeding. The reported incidence of ISAH in Spain $(27,47 \%$ in Barcelona $^{40}, 30,9 \%$ in Valencia ${ }^{48}, 27 \%$ in Madrid ${ }^{33}$ ), is traditionally higher than in other countries. Managing patients with SAH of unknown origin can be a challenge, because of the uncertainty of their evolution and the lack of evidence about best management measures, but there are few large or multicentre series' reports about ISAH I $^{4,38,20,56,75}$.

The SENEC Vascular Pathology Group from Spain designed a multicentre data base registry on spontaneous SAH. In a 3 year period, 1.149 consecutive patients were collected by the 16 participant hospitals distributed over the whole Spanish geography ${ }^{35}$. In 220 of these patients no cause of the bleeding could be discovered angiographically, constituting the ISAH group. Epidemiological, clinical and prognostic outcome factors from this group of patients are analyzed in this report, to reflect the real problematic derived from the management of this pathology in a group of public health hospitals in Spain.

\section{Materials and methods}

The SENEC Vascular Group SAH data base has been clearly explained in a previous publication ${ }^{35}$. Between November 2004 and November 2007, 1.149 spontaneous SAH patient cases were collected. Traumatic SAH was excluded. Convexity type SAH was also excluded by consensus because it is usually secondary to defined pathologies with different diagnostic and treatment protocols ${ }^{38,49}$.

From the 1.149 total cases, $929(81 \%)$ were aneurismal SAH (ANSAH), including 55 patients who died before angiography. The 220 patients left (19\%) had no angiographically demonstrable SAH blood source constituting the idiopathic group (ISAH) analyzed in the present study.

The Data Base analysis variables included clinical background (age, sex, history of arterial hypertension, smoking habit, and diabetes), clinical situation on admission (measured by GCS and WFNS scale), radiological data (day of the diagnostic CT and SAH Fisher grade), ICU admission, SAH complications (rebleeding, vasospasm, hydrocephalus), and finally, initial and final outcome, on hospital discharge and at 6 months respectively, measured by the Glasgow Outcome Scale (GOS).

A variable specific to ISAH patients was the CT pattern of blood distribution, classified as 3 possible types: Van Gijn and Rinkel's perimesencephalic pattern (pmISAH) ${ }^{52,70}$; aneurysmal, classical or diffuse pattern (anISAH); and normal CT (clinical and lumbar puncture diagnosis of $\mathrm{SAH})$. The number of angiographic studies performed on each patient to rule out aneurysm has also been recorded, varying into one or two studies.

These variables were analyzed in the ISAH group and in the blood CT pattern ISAH subgroups; and the results were compared to the group of ANSAH patients. The variables were processed with the 15.0 version SSPS statistical program for Windows, considering significant differences if $p$ value $<0,05$. Variables among different ISAH groups were compared by means of Pearson's chi-square test, or the Fisher's test or the Yate's continuity correction where appropriate, for qualitative variables; and by student's $t$ test for independent samples for quantitative variables. A univariate analysis was made to determine the association of different variables to initial and final outcome. A multivariate logistic regression analysis was done to determine those variables maintaining their independent effect influencing patient's outcome, after adjustment with the rest of variables. Finally, we essayed the Lagares et al. ${ }^{34}$ SAH five grade prognostic scale based on a combination of 3 variables that can be quickly and easily recorded in the acute stage: age of the patient, WFNS on admission, and SAH Fisher's grade. We sought to explore if prognostic escalation could be obtained with the application of the scale in the respective series of ISAH and ANSAH.

\section{Results}

\section{ISAH general aspects}

The 220 patients constituting the ISAH group represent $19 \%$ of the whole SAH series of 1.149 patients.

Sex distribution showed a male predominance $(55 \%$ male and $45 \%$ female), with no significant differences in the 3 ISAH blood CT pattern subgroups.

Mean age of ISAH patients was 55,17 years, with a significant tendency for patients older than 60 years of age to present an aneurysmal CT blood pattern (anISAH) compared to perimesencephalic CT blood pattern (pmISAH), 


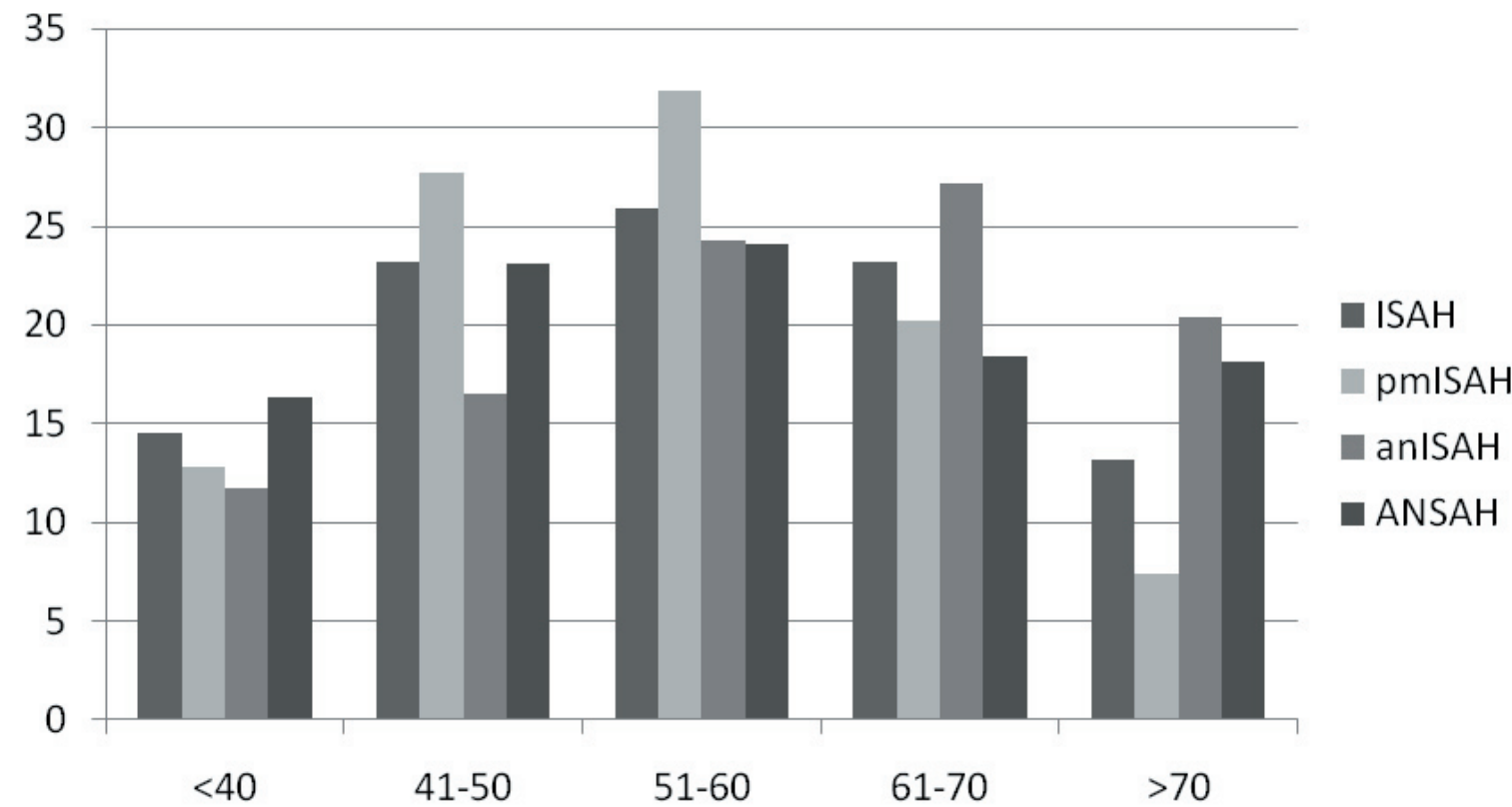

Figure 1. Analysis of age at presentation among the different SAH groups.

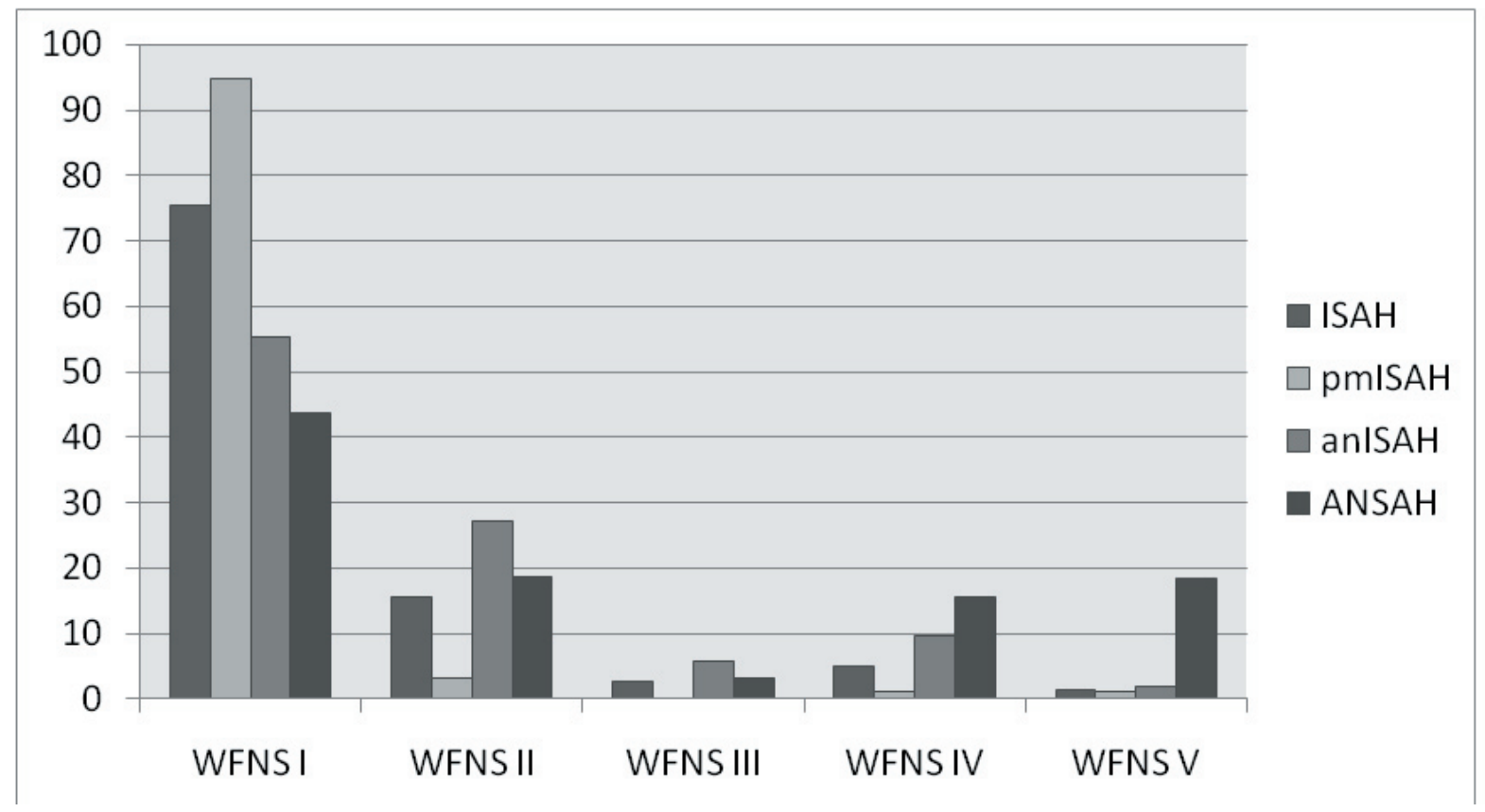

Figure 2. Comparison of WFNS admission grades among the different types of SAH.

$(\mathrm{p}=0,008)$. (Figure 1).

We have not found any seasonal or day of the week preference for the occurrence of ISAH.

History of arterial hypertension was present in 30,5\% of ISAH patients; 30,9\% had smoking habits; and 14,5\% had history of diabetes. (Table 1) The frequency of arterial hypertension is significantly higher among anISAH patients $(38,8 \%)$, compared to pmISAH patients $(21,3 \%)$, $(\mathrm{p}=0,026)$, but smoking habits and frequency of diabetes are similar in all CT pattern groups.

Admission clinical status was grade I WFNS in 75,5\% of ISAH patients and grade II WFNS in $15,5 \%$. There is also a significant difference between clinical admission status of anISAH patients (55,3\% in grade I WFNS) and the other ISAH patients $(90 \%$ of normal CT and $94 \%$ of pmISAH patients in grade I WFNS), $(\mathrm{p}<0,0001)$. (Figure 2). 
Table 1

Table showing the comparison of clinical, radiological and outcome variables between the groups of ISAH and ANSAH

\begin{tabular}{|c|c|c|c|c|}
\hline & & $\begin{array}{c}\text { ISAH } \\
(\mathrm{n}=220)\end{array}$ & $\begin{array}{l}\text { ANSAH } \\
(\mathrm{n}=929)\end{array}$ & $\mathrm{p}$ \\
\hline \multicolumn{2}{|c|}{$\begin{array}{l}\text { Median age in years } \\
\text { (95\% Confidence Interval) }\end{array}$} & $\begin{array}{c}55^{\prime} 17 \\
(53,36-56,98)\end{array}$ & $\begin{array}{c}55^{\prime} 15 \\
(54,20-56,09)\end{array}$ & $\begin{array}{l}\text { Non } \\
\text { significan }\end{array}$ \\
\hline \multirow{2}{*}{ Sex } & female & $45 \%(99)$ & $59,6 \%(551)$ & \multirow{2}{*}{$\mathrm{p}<0$ 0’001 } \\
\hline & male & $55 \%(153)$ & $40,4 \%(373)$ & \\
\hline \multicolumn{2}{|c|}{ History of arterial hypertension } & $30,5 \%(67)$ & $43,5 \%(404)$ & $\mathrm{p}<0 ’ 001$ \\
\hline \multicolumn{2}{|l|}{ Smoking habit } & $30,9 \%(68)$ & $39,2 \%(364)$ & $\mathrm{p}=0^{\prime} 023$ \\
\hline \multicolumn{2}{|c|}{ History of Diabetes } & $14,5 \%(32)$ & $8,7 \%(81)$ & $\mathrm{p}=0$ ’009 \\
\hline \multirow{4}{*}{ SAH Fisher grade } & 1 & $10,4 \%(23)$ & $4,2 \%(39)$ & \multirow{4}{*}{$\mathrm{p}<0,001$} \\
\hline & 2 & $47,2 \%(104)$ & $17 \%(158)$ & \\
\hline & 3 & $21,4 \%(47)$ & $32,9 \%(306)$ & \\
\hline & 4 & $20,9 \%(46)$ & $45,9 \%(426)$ & \\
\hline \multicolumn{2}{|l|}{ Rebleeding } & $3,6 \%(8)$ & $10,5 \%(98)$ & $\mathrm{p}=0,001$ \\
\hline \multirow{2}{*}{ Vasospasm } & Angiographic & $4,5 \%(10)$ & $10,3 \%(96)$ & \multirow{2}{*}{$\mathrm{p}<0,001$} \\
\hline & Clinical & $2,7 \%(6)$ & $25,8 \%(240)$ & \\
\hline \multirow{2}{*}{ Hydrocephalus } & Temporal & $10 \%(22)$ & $18,3 \%(170)$ & \multirow{2}{*}{$\mathrm{p}<0,001$} \\
\hline & Permanent & $3,2 \%(7)$ & $9,1 \%(85)$ & \\
\hline \multirow{5}{*}{ GOS } & $\begin{array}{l}\text { Good } \\
\text { Recovery }\end{array}$ & $87,2 \%(192)$ & $39,55 \%(367)$ & \multirow{5}{*}{$\mathrm{p}<0,001$} \\
\hline & \begin{tabular}{|l} 
Moderate \\
Disability
\end{tabular} & $3,6 \%(8)$ & $17,8 \%(165)$ & \\
\hline & \begin{tabular}{|l|} 
Severe \\
Disability
\end{tabular} & $1,8 \%(4)$ & $13,7 \%(127)$ & \\
\hline & $\begin{array}{l}\text { Vegetative } \\
\text { State }\end{array}$ & 0 & $2,5 \%(23)$ & \\
\hline & Dead & $7,3 \%(16)$ & $25,6 \%(238)$ & \\
\hline
\end{tabular}

Globally, $44,5 \%$ of ISAH patients were admitted into the ICU, but the proportion of anISAH patients admitted is significantly higher than the corresponding to pmISAH patients (58,3\% and $27,7 \%$ respectively), $(p<0,0001)$.

\section{ISAH radiological variables}

Diagnostic CT was obtained in the first 24-48 hours after the clinical bleeding episode in $89 \%$ of anISAH, $84 \%$ of pmISAH, and $70 \%$ of normal CT ISAH patients.

Blood pattern on CT was aneurysmal in 103 ISAH patients $(46,8 \%)$, perimesencephalic in $94(42,7 \%)$ and normal CT in 23 cases $(10,4 \%)$.

Blood CT Fisher grade in ISAH patients (Table 1) was predominantly grade $2(47,2 \%$ of ISAH patients) and less frequently grade $3(21,4 \%)$ or $4(20,9 \%)$. Higher Fisher grades (grades 3-4) significantly correlated with aneu- 
Table 2

Variables that show significant influence on ISAH patients' outcome by univariate analysis. (Bad outcome groups the GOS dead and severely disabled patients)

\begin{tabular}{|c|c|c|c|}
\hline Variable & $\begin{array}{c}\text { ISAH } \\
(n=220)\end{array}$ & $\begin{array}{l}\% \text { bad outcome } \\
\text { (n) }\end{array}$ & $\mathrm{p}$ \\
\hline \multirow{2}{*}{ Sex } & $\begin{array}{l}\text { Male } \\
(121)\end{array}$ & $\begin{array}{l}8,26 \% \\
(10)\end{array}$ & \multirow{2}{*}{$\mathrm{p}=0,02$} \\
\hline & $\begin{array}{l}\text { Female } \\
\text { (99) }\end{array}$ & $\begin{array}{l}10,10 \% \\
(10)\end{array}$ & \\
\hline \multirow{2}{*}{ Age } & $\begin{array}{l}<60 \text { years } \\
(140)\end{array}$ & $\begin{array}{l}5 \% \\
(7)\end{array}$ & \multirow{2}{*}{$\mathrm{p}=0,006$} \\
\hline & $\begin{array}{c}>60 \text { years } \\
(80)\end{array}$ & $\begin{array}{l}16,25 \% \\
(13)\end{array}$ & \\
\hline \multirow{2}{*}{ Arterial hypertension } & $\begin{array}{l}\text { Present } \\
(67)\end{array}$ & $\begin{array}{l}17,91 \% \\
(12)\end{array}$ & \multirow{2}{*}{$\mathrm{p}=0,003$} \\
\hline & $\begin{array}{l}\text { Absent } \\
(153)\end{array}$ & $\begin{array}{l}5,22 \% \\
(8)\end{array}$ & \\
\hline \multirow{2}{*}{ WFNS } & $\begin{array}{c}1-3 \\
(206)\end{array}$ & $\begin{array}{l}6,79 \% \\
(14)\end{array}$ & \multirow{2}{*}{$\mathrm{p}<0,001$} \\
\hline & $\begin{array}{l}4-5 \\
(14)\end{array}$ & $\begin{array}{l}42,85 \% \\
\text { (6) }\end{array}$ & \\
\hline \multirow{2}{*}{ CT blood pattern } & $\begin{array}{l}\text { anISAH } \\
(103)\end{array}$ & $\begin{array}{l}16,50 \% \\
(17)\end{array}$ & \multirow{2}{*}{$\mathrm{p}=0,001$} \\
\hline & $\begin{array}{l}\text { pmISAH and normal } \\
\text { (117) }\end{array}$ & $\begin{array}{l}2,56 \% \\
(3)\end{array}$ & \\
\hline \multirow{2}{*}{ Fisher grade } & $\begin{array}{c}1-2 \\
(127)\end{array}$ & $\begin{array}{l}2,36 \% \\
(3)\end{array}$ & \multirow{2}{*}{$\mathrm{p}=0,001$} \\
\hline & $\begin{array}{l}3-4 \\
(93)\end{array}$ & $\begin{array}{l}18,27 \% \\
(17)\end{array}$ & \\
\hline \multirow{2}{*}{ ICU admission } & $\begin{array}{l}\text { Yes } \\
(98)\end{array}$ & $\begin{array}{l}16,32 \% \\
\quad(16)\end{array}$ & \multirow{2}{*}{$\mathrm{p}=0,001$} \\
\hline & $\begin{array}{c}\text { No } \\
(122)\end{array}$ & $\begin{array}{l}3,27 \% \\
(4)\end{array}$ & \\
\hline \multirow{2}{*}{ Rebleeding } & $\begin{array}{l}\text { Yes } \\
(8)\end{array}$ & $\begin{array}{c}62,5 \% \\
(5)\end{array}$ & \multirow{2}{*}{$\mathrm{p}<0,001$} \\
\hline & $\begin{array}{c}\text { No } \\
(212)\end{array}$ & $\begin{array}{c}7,07 \% \\
(15)\end{array}$ & \\
\hline \multirow{2}{*}{ Vasospasm } & $\begin{array}{l}\text { Yes } \\
(16)\end{array}$ & $\begin{array}{l}25 \% \\
(4)\end{array}$ & \multirow{2}{*}{$\mathrm{p}=0,001$} \\
\hline & $\begin{array}{l}\text { No } \\
(204)\end{array}$ & $\begin{array}{l}7,84 \% \\
(16)\end{array}$ & \\
\hline \multirow{2}{*}{ Hydrocephalus } & $\begin{array}{l}\text { Yes } \\
(29)\end{array}$ & $\begin{array}{l}24,13 \% \\
\quad(7)\end{array}$ & \multirow{2}{*}{$\mathrm{p}=0,003$} \\
\hline & $\begin{array}{c}\text { No } \\
(191)\end{array}$ & $\begin{array}{l}6,80 \% \\
(13)\end{array}$ & \\
\hline
\end{tabular}


rysmal blood pattern on $\mathrm{CT}(\mathrm{p}<0,0001)$. There was no correlation between Fisher's grade and appearance of vasospasm. Fisher grade 4 was significantly related to hydrocephalus $(\mathrm{p}<0,001)$.

All ISAH patients had at least one negative complete cerebral angiography. Only $28,6 \%$ of ISAH patients had a second cerebral angiography, which was done significantly more frequently for anISAH cases $(43,1 \%)$ than for pmISAH cases $(19,1 \%),(p<0,001)$. None of the 16 ISAH patients that finally died had a second angiogram done, but the majority of these patients died within two weeks from admission (13/16) and all within 3 weeks.

\section{ISAH Complications and outcome}

Eight ISAH patients $(3,6 \%)$ experienced rebleeding: 5 within the anISAH Group and 3 within the pmISAH Group, (no statistical difference). (Table 1).

Sixteen ISAH patients $(7,3 \%)$ presented radiological or clinical vasospasm, with no statistical differences among blood pattern subgroups. Vasospasm was significantly related to rebleeding $(p=0,042)$.

Temporary ventricular drainage was required in $10 \%$ of ISAH patients. Permanent ventricular shunt device was required in $3,2 \%$ of ISAH patients. Temporary or definitive hydrocephalus was significantly more frequent among anISAH patients $(17,5 \%$ and $3,9 \%$ respectively), ( $\mathrm{p}=$ $0,007)$. Hydrocephalus was significantly related to Fisher grade $4(\mathrm{p}<0,001)$ and rebleeding $(\mathrm{p}=0,003)$.

Good initial outcome was achieved in $89,5 \%$ of ISAH patients. There were 16 deaths (7,3\% of ISAH cases), of which 14 belong to the anISAH subgroup, 1 to the pmISAH subgroup and 1 to the normal CT subgroup. Death was related to rebleeding in 5 cases, to acute hydrocephalus in 2 cases, and to severe vasospasm in 2 cases. The other 7 deaths were related to bad clinical condition on admission (WFNS IV or V) in 4 cases, and to serious medical complications in 3 patients (respiratory distress in 2 and drug-abuse related complications in one). The pmISAH dead patient suffered a ventricular massive rebleeding on the $10^{\text {th }}$ day, previous to the scheduled second angiography, but showing CTA and MRA both negative in the interval. The dead patient with normal CT on admission had the diagnostic CT done on the sixth day of evolution when the patient presented with clinical deterioration secondary to hydrocephalus, and later on suffered clinical vasospasm in the context of serious comorbidities.

Final outcome at six months was good in $91,2 \%$ of ISAH patients and poor in $8,8 \%$. There were 2 extra deaths after hospital discharge, both related to medical complications and not to rebleeding.

\section{ISAH Outcome related variables}

Table 2 contains those ISAH variables that significantly influenced outcome.

Males tend to recover better than females $(p=0,02)$. Age older than 60 years significantly relates to worse outcome $(\mathrm{p}=0,006)$, as it occurs with history of arterial hypertension $(\mathrm{p}=0,003)$. Clinical admission grade measured by GCS or WFNS is significantly associated to outcome $(\mathrm{p}<0,001)$ in a straight relationship: higher grades show worse outcome. Aneurysmal CT blood pattern significantly correlated to bad outcome $(\mathrm{p}=0,001)$ as did Fisher blood CT grades 3-4 $(\mathrm{p}=0,001)$. Finally, ICU admission $(\mathrm{p}=0,001)$ and the presence of SAH complications, i.e., rebleeding $(p<0,001)$, hydrocephalus $(p=0,003)$ and vasospasm $(p=0,001)$, were all significantly related to worse outcome.

The same epidemiological, clinical, radiological, and course variables except sex, keep their statistical significance when analyzing final outcome at 6 months.

When performing a multivariate analysis with logistic regression to determine which variables keep their specific weight influencing outcome, only the neurological status on admission followed by the age of the patient, are left. The essay to apply the Lagares et $\mathrm{al}^{34}$ prognostic scale to ISAH cases did not improve significantly the prognostic value obtained by the isolated use of the WFNS neurological status on admission.

\section{Comparison between ISAH and ANSAH groups}

The aneurysmal SAH Group is formed by 929 patients ( $81 \%$ of the total).

The clinical, radiological, complication rate and outcome variables differences amongst ANSAH and ISAH groups are described in Table 1.

Sex distribution in ANSAH favours women (59,6\% are females), which is significantly different from the ISAH group, $(\mathrm{p}<0,001)$. Neither median age in the ANSAH group $(55,15$ years of age), nor age distribution by decades, are significantly different from those in the ISAH group.

As with ISAH group, there is no seasonal or day of the week predominance for the occurrence of ANSAH.

History of arterial hypertension and smoking habits are significantly more frequent among ANSAH patients ( $\mathrm{p}<0,001$ and $\mathrm{p}<0,023$ respectively), but history of diabetes is significantly more common among ISAH patients $(\mathrm{p}=0,009)$.

Neurological status on admission measured by GCS and WFNS is significantly worse in ANSAH cases, $(p<0,001)$. (Figure 2)

The majority of ANSAH patients $(83,5 \%)$ were admitted to the ICU, which is a proportion significantly different from the ISAH patients, $(p<0,001)$.

ANSAH cases present with greater amounts of blood on CT compared to ISAH patients, $(p<0,001)$. All three SAH complications, rebleeding $(\mathrm{p}=0,001)$, vasospasm 
( $p<0,001)$ and hydrocephalus ( $p<0,001)$, were significantly more frequent in ANSAH than in ISAH patients.

Finally, outcome was significantly worse in ANSAH patients $(\mathrm{p}<0,001)$ with good outcome in only $57,8 \%$ and a mortality rate of $25,9 \%$, compared to ISAH patients. (Table 1) The application of prognostic scales to the ANSAH group, as the one proposed by Lagares et $\mathrm{al}^{34}$, is of great value because it clearly defines a significant grading escalation in this group of patients by means of considering the patient's age, the WFNS on admission and the SAH Fisher's grade on CT.

\section{Discussion}

Although there are inherent difficulties in obtaining clinical data registries encompassing various hospitals, the information derived from these multicentre data is invaluable to understand the real problematic of a certain pathology within a big community, not only in epidemiological terms but also looking to therapeutic management and results. Lagares et al. ${ }^{35}$ have clearly defined the characteristics and benefits of a multicentre registry on spontaneous SAH sustained in a portal web shared by 16 hospitals from Spain. The collected series of 220 cases of ISAH constitutes a gold opportunity to study the characteristics of this pathology in our country.

Our ISAH series represents 19\% of the total spontaneous SAH series, that is a percentage above the higher limit of the $5-15 \%$ usually cited in the literature ${ }^{6,15,25,45,53,60,65,67,79}$, but it has diminished compared to the $25-30 \%$ cited by previous Spanish series ${ }^{33,40,46,48,57}$, meaning that the diagnostic advances in our health system in the last years have favourably influenced aneurysmal detection as the cause of spontaneous $\mathrm{SAH}$, in a way similar to other medical communities ${ }^{21}$.

We haven't evidenced any seasonal or day of the week preference pattern for SAH occurrence either for the ANSAH nor the ISAH groups, similar to other studies ${ }^{56}$. Although this finding is controversial in the literature for ANSAH $^{8,22,40}$, there are scarce data mentioning possible seasonal or circadian patterns in the particular case of $\mathrm{ISAH}^{72}$.

Sex distribution favours men in our ISAH series, contrary to the female preponderance in ANSAH, in accordance with other series ${ }^{15,33,61}$. Median age of 55 years in ISAH and ANSAH groups is also comparable to other series, although there are small oscillations in different ISAH series depending on the proportion of patients with pmISAH which varies between 21 to $68 \%$, because this type of ISAH is said to affect younger patients ${ }^{15,61,67}$. In our series an original finding was the greater proportion of patients older than 60 years of age in the anISAH compared to the other subgroups of ISAH.
2010; 21:441-451

Incidence of arterial hypertension and smoking habits, recognized as risk factors for $\mathrm{ANSAH}^{11,54}$, is significantly smaller among ISAH patients in our series. Some reports emphasize the lesser incidence of arterial hypertension amongst ISAH patients ${ }^{11,15,33}$, but there are also clinical reports attributing a causal role to hypertension in ISAH $^{11,41,64}$. Anyway, although arterial hypertension is considered a risk factor for ANSAH, most authors believe that it is not as much the case for $\mathrm{ISAH}^{28}$, particularly if we consider pmISAH which probably responds to different causal patterns ${ }^{66}$.

On the contrary, diabetes affects significantly more frequently ISAH cases compared to ANSAH patients. In our series the percentage of diabetes in the ISAH group doubles the ANSAH one. Canhao ${ }^{11}$ also found more incidence of diabetes among pmISAH patients compared to a control group. In a study of Ruiz Sandoval ${ }^{56}$ the incidence of diabetes among ANSAH patients is significantly smaller compared to a control group population. Feigin et al. ${ }^{14}$ in a revision of SAH risk factors conclude that diabetes is associated with a reduced risk for ANSAH for unknown reasons.

Moreover, there are significant differences in between perimesencephalic ISAH and aneurysmal ISAH subgroups when considering the incidence of arterial hypertension, but not for diabetes or smoking habits. It could be speculated that different vascular risk factors relate to different types of SAH. Among ISAH cases, those with aneurysmal pattern of blood are nearer clinically to aneurysmal SAH patients, but with no visible angiographic lesion, creating the suspicion that anISAH might be secondary to an arterial blood source representing some sort of form frustra of arterial pathology, different from the probable venous origin in pmISAH ${ }^{18,29,36,61}$.

ISAH patients present with better clinical grades on admission and less amount of blood on CT measured by Fisher's grade, compared to ANSAH patients in our series. It is relevant that less than half of ISAH patients were admitted to the ICU compared to $83,5 \%$ of ANSAH patients, meaning that ISAH is associated to a lower risk suspicion than ANSAH on admission. Moreover, this misconception is reinforced because ISAH tends to present less complications related to hydrocephalus and vasospasm, and a relatively low rebleeding rate. This false perception of ISAH benignity is still continuously debated ${ }^{18,44,75}$. It can also be stressed here that ICU admissions in our series were significantly higher among anISAH patients than for pmISAH patients.

We have found a predominance of aneurysmal CT pattern over perimesencephalic pattern in ISAH, although the proportion of early diagnostic CT ( $<48$ hours) is similar in both patterns. On the other hand, the high percentage of normal CT $(10,4 \%$ of ISAH) could be related to the fact 
that almost one third of them had their diagnostic CT done more than 72 hours after the bleeding episode, and CT sensitivity for SAH diminishes dramatically after 3 days ${ }^{10}$. In general, the reported ISAH series that differentiate blood pattern subtypes on $\mathrm{CT}$, support a higher frequency of the more suspicious aneurysmal pattern than the perimesencephalic one ${ }^{15,20,21,25,33,38,51,79}$.

The pmISAH type has been a matter of multiple reports in the literature ${ }^{50,61,62,69,70}$, but many questions are still unsolved, as the origin of the $\mathrm{SAH}$ itself from an $\operatorname{arterial}^{37,42,47,59,74}$, or a venous source ${ }^{15,36,41,43,58,70}$. There is also an interesting debate about the possible relation between pmISAH and some profound venous system variants or anomalies $3,13,68,73,77$.

Controversy also affects the decision of how many radiological examinations should be performed in pmISAH cases to rule out the possibility of false negative angiogram for posterior circulation aneurysm $\mathrm{s}^{2,69,71,76}$. In our series, only $19 \%$ of pmISAH cases had a second cerebral angiogram done. Some recent reports state that only one complete angiogram is required in this type of SAH and even only CT angiography ${ }^{1,5,9,19,26,55,71}$. Greebe and Rinkel ${ }^{17}$ revised life expectancy in 160 patients who suffered pmISAH diagnosed by CT angiography, evidencing no risk of rebleeding after a median 7,5 year follow-up.

The majority of authors agree that pmISAH is a benign process, even though it can sometimes be complicated with severe vasospasm and even rebleeding ${ }^{21,44,60}$. In our series, the incidence of rebleeding and vasospasm among pmISAH patients is similar to that related to anISAH patients, and only hydrocephalus is less frequent in pmISAH patients. Amongst our 94 pmISAH patients we had one death and one severe disability, summing up two bad outcomes. Other published series prevent about lessening caution in the acute phase of the illness, mostly if there is any deviation from the classic perimesencephalic bleeding criteria ${ }^{20,75}$.

The anISAH type constitutes the more dangerous and troublesome group because it presents some similarities with true ANSAH in terms of clinical grade, Fisher grade and even outcome. In our series, anISAH has been related to older age, worse neurological status on admission, more incidence of arterial hypertension, higher Fisher blood CT grades, more frequent hydrocephalus, and worse outcome compared to other types of ISAH. Fourteen of the sixteen ISAH deaths belong to this CT blood pattern, a fact that emphasizes the differences between this group and the other ISAH patterns. This feature is in concordance with previous publications ${ }^{20,25,33}$ and reinforces the importance of keeping the ISAH CT blood pattern classification.

Many series evidence that anISAH is the type more frequently associated to a first false negative angiography in 2 to $24 \%$ of cases, reaching $45,9 \%$ of Jung's series ${ }^{21,23,33,38}$. Many reported diagnostic and management algorithms try to avoid false negative diagnosis of aneurysmal source of the $\mathrm{SAH}^{5,24,27,38,57,67}$. Diagnostic efforts in these patients should include a second and a third angiogram ${ }^{21,36,39,67}$ and even surgical exploration in selected cases $^{38,60,65}$. Less than half of our anISAH cases had a second angiogram performed, far from the $100 \%$ recommendation made by many authors $5,18,20,23,24,38$. Anyway, our series confirm the results of other reports ${ }^{7,12,16,20,25,33,45}$ in that, once the acute phase has been overcome, the anISAH patients' clinical evolution is significantly better than ANSAH patients, with no rebleedings from discharge until final outcome at six months.

Morbidity and mortality numbers in our series are in consonance with those reported in the literature. Ildan's et al ISAH series ${ }^{21}$ reports $4,7 \%$ of rebleeding complications; $17,8 \%$ of ischemic complications; $4,7 \%$ of hydrocephalus; and an $8,3 \%$ mortality, with one death attributed to rebleeding in a case of pmISAH. It is possible that the 5 patients in our series whose death was attributed to rebleeding could have actually died due to a non diagnosed cause of SAH. In fact, there was no previous accordance among the participant hospitals relating to the number of complementary examinations required for diagnosis. None of the 16 dead patients had a second angiogram done, but almost all died in the acute phase or presented serious medical complications, probably with no opportunity for performing the second angiography even though it would have been scheduled. We do understand that this is a limitation of our study and these results will surely promote a revision of our hospital protocols in the sense of greater diagnostic efforts.

Finally, the ISAH data base multivariate analysis demonstrated that the neurological status on admission was the only factor with definite influence on outcome. This fact is not surprising if we consider the evidence supported by other studies ${ }^{30,32,78}$ that SAH related bad outcome and death is primarily due to the brain damage induced by the acute bleeding. The problem with ISAH series is that a great majority of these patients have good clinical condition on admission and good outcome, making it difficult to discern groups of risk by identifying statistically relevant clinical factors. And even though an aneurysmal pattern of blood implies a higher risk of complications and death in ISAH patients, there is also a non negligible incidence of complications among the subgroups of ISAH with apparently more benign blood CT patterns as the perimesencephalic type.

\section{Summary}

In our country, the incidence of ISAH among spontaneous SAH is diminishing.

It makes sense to maintain classification of ISAH depending on the blood CT pattern to differentiate high risk groups. 
Neurological status on admission is the most valuable prognostic factor for ISAH patients' outcome.

The SENEC spontaneous SAH data base continues open for registries and it is foreseeable that its results will help us to improve our management protocols and our understanding of this serious illness.

\section{Bibliography}

1. Agid, R., Andersson, T., Almqvis,t H., et al.: Negative CT angiography findings in patients with spontaneous subarachnoid hemorrhage: When is digital subtraction angiography still needed? AJNR Am J Neuroradiol 2010; 31: 696-705.

2. Alen, J., Lagares, A., Lobato, R., Gomez, P., Rivas, J., Ramos, A.: Comparison between perimesencephalic nonaneurysmal subarachnoid hemorrhage and subarachnoid hemorrhage caused by posterior circulation aneurysms. J Neurosurg 2003; 98: 529-535.

3. Alen, J., Lagares, A., Campollo, J., Ballenilla, F., Kaen, A., Nunez, A., Lobato, R.: Idiopathic subarachnoid hemorrhage and venous drainage: are they related? Neurosurgery 2008; 63:1106-1112.

4. Alexander, M., Dias, P., Uttley, D.: Spontaneous subarachnoid hemorrhage and negative cerebral panangiography. Review of 140 cases. J Neurosurg 1986; 64: 537-542.

5. Andaluz, N., Zuccarello, M.: Yield of further diagnostic work-up of cryptogenic subarachnoid hemorrhage based on bleeding patterns on computed tomographic scans. Neurosurgery 2008; 62: 1040-1046; discussion 1047.

6. Arauz, A., Lopez, M., Cantu, C., Barinagarrementeria, F.: Nonaneurysmal subarachnoid hemorrhage. Study of longterm follow-up. Neurología 2007; 22: 502-506.

7. Berdoz, D., Uske, A., de Tribolet, N.: Subarachnoid haemorrhage of unknown cause: Clinical, neuroradiological and evolutive aspects. J Clin Neurosci 1998; 5: 274-282.

8. Beseoglu, K., Hanggi, D., Stummer, W., Steiger, H.: Dependence of subarachnoid hemorrhage on climate conditions: a systematic meteorological analysis from the Dusseldorf metropolitan area. Neurosurgery 2008; 62: 1033-1038; discussion 1038-1039.

9. Brinjikji, W., Kallmes, D., White, J., Lanzino, G., Morris, J., Cloft, H.: Inter- and Intraobserver Agreement in CT Characterization of Nonaneurysmal Perimesencephalic Subarachnoid Hemorrhage. AJNR Am J Neuroradiol 2010; 31: 1103-1105.

10. Byyny, R., Mower, W., Shum, N., Gabayan, G., Fang, S., Baraff, L.: Sensitivity of noncontrast cranial computed tomography for the emergency department diagnosis of subarachnoid hemorrhage. Ann Emerg Med 2008; 51: 697-703.

11. Canhao, P., Falcao, F., Pinho e Melo, T., Ferro, H., Ferro, J.: Vascular risk factors for perimesencephalic nonaneurysmal subarachnoid hemorrhage. J Neurol 1999; 246: 492-496.

12. Cánovas, D., Gil, A., Jato, M., Rubio, F.: Non-aneurys- mal subarachnoid hemorrhage: 60 cases. Neurologia 2006; 21 : 704-709.

13. Daenekindt, T., Wilms, G., Thijs, V., Demaerel, P., Van Calenbergh, F.: Variants of the basal vein of Rosenthal and perimesencephalic nonaneurysmal hemorrhage. Surg Neurol 2008; 69: 526-529; discussion 529.

14. Feigin, V., Rinkel, G., Lawes, C., Algra, A., Bennett, D., van Gijn, J., Anderson, C.: Risk factors for subarachnoid hemorrhage: an updated systematic review of epidemiological studies. Stroke 2005; 36: 2773-2780.

15. Flaherty, M., Haverbusch, M., Kissela, B., et al.: Perimesencephalic subarachnoid hemorrhage: incidence, risk factors, and outcome. J Stroke Cerebrovasc Dis 2005; 14: 267-271.

16. Gomez, P., Lobato, R., Rivas, J., et al.: Subarachnoid haemorrhage of unknown aetiology. Acta Neurochir (Wien) 1989; 101: 35-41.

17. Greebe, P., Rinkel, G.: Life Expectancy After Perimesencephalic Subarachnoid Hemorrhage. Stroke 2007; 38: $1222-1224$.

18. Gupta, S., Gupta, R., Khosla, V., et al.: Nonaneurysmal nonperimesencephalic subarachnoid hemorrhage: is it a benign entity? Surg Neurol 2009; 71: 566-571.

19. Hashimoto, H., Iida, J., Hironaka, Y., Okada, M., Sakaki, T.: Use of spiral computerized tomography angiography in patients with subarachnoid hemorrhage in whom subtraction angiography did not reveal cerebral aneurysms. J Neurosurg 2000; 92: 278-283.

20. Hui, F., Tumialan, L., Tanaka, T., Cawley, C., Zhang, Y.: Clinical Differences Between Angiographically Negative, Diffuse Subarachnoid Hemorrhage and Perimesencephalic Subarachnoid Hemorrhage. Neurocrit Care 2009; 11: 64-70.

21. Ildan, F., Tuna, M., Erman, T., Gocer, A., Cetinalp, E., Burgut, R.: Prognosis and prognostic factors for unexplained subarachnoid hemorrhage: review of 84 cases. Neurosurgery 2002; 50: 1015-1024; discussion 1024-1015.

22. Inagawa, T.: Seasonal variation in the incidence of aneurysmal subarachnoid hemorrhage in hospital- and community-based studies. J Neurosurg 2002; 96: 497-509.

23. Jung, J., Kim, Y., Lee, J., Huh, S., Lee, K.: Spontaneous subarachnoid haemorrhage with negative initial angiography: a review of 143 cases. J Clin Neurosci 2006; 13: 1011-1017.

24. Kaim, A., Proske, M., Kirsch, E., von Weymarn, A., Radu, E.W., Steinbrich, W.: Value of repeat-angiography in cases of unexplained subarachnoid hemorrhage (SAH). Acta Neurol Scand 1996; 93: 366-373.

25. Kang, D., Park, J., Lee, S., Park, S., Kim, Y., Hamm, I.: Does non-perimesencephalic type non-aneurysmal subarachnoid hemorrhage have a benign prognosis? J Clin Neurosci 2009; 16: 904-908.

26. Kershenovich, A., Rappaport, Z., Maimon, S.: Brain computed tomography angiographic scans as the sole diagnostic examination for excluding aneurysms in patients with perimesencephalic subarachnoid hemorrhage. Neurosurgery 
2006; 59: 798-801; discussion 801-792.

27. Khan, N., Schuknecht, B., Yonekawa, Y.: Presentation and management of patients with initial negative 4-vessel cerebral angiography in subarachnoid hemorrhage. Acta Neurochir Suppl 2002; 82: 71-81.

28. Kleinpeter, G., Lehr, S.: Characterization of risk factor differences in perimesencephalic subarachnoid hemorrhage. Minim Invasive Neurosurg 2003; 46: 142-148.

29. Kocaeli, H., Chaalala, C., Andaluz, N., Zuccarello, M.: Spontaneous intradural vertebral artery dissection: a singlecenter experience and review of the literature. Skull Base 2009; 19: 209-218.

30. Komotar, R., Schmidt, J., Starke, R., et al.: Resuscitation and critical care of poor-grade subarachnoid hemorrhage. Neurosurgery 2009; 64: 397-410; discussion 410-391.

31. Kozàc, N., Hayashi, M.: Trends in the incidence of subarachnoid hemorrhage in Akita Prefecture, Japan. J Neurosurg 2007; 106: 234-238.

32. Lagares, A., Gomez, P., Lobato, R., Alen, J., Alday, R., Campollo, J.: Prognostic factors on hospital admission after spontaneous subarachnoid haemorrhage. Acta Neurochir (Wien) 2001; 143: 665-672.

33. Lagares, A., Gómez, P., Lobato, R., et al.: Idiopathic subarachnoid hemorrhage; comparison of different bleeding patterns and long-term outcome. Neurocirugia 2002; 13: 110-119.

34. Lagares, A., Gómez, P., Alen, J., et al.: A comparison of different grading scales for predicting outcome after subarachnoid haemorrhage. Acta Neurochir (Wien) 2005; 147: 5-16; discussion 16.

35. Lagares, A., de Toledo, P., Fernández-Alén, J., et al.: Spontaneous Subarachnoid Haemorrhage multicenter database from the Group for the Study of Vascular Pathology of the Spanish Society for Neurosurgery: Presentation, inclusion criteria and development of an internet-based registry. Neurocirugia 2008; 19: 405-415.

36. Lang, E.W., Khodair, A., Barth, H., Hempelmann, R.G., Dorsch, N.W., Mehdorn, H.M.: Subarachnoid hemorrhage of unknown origin and the basilar artery configuration. J Clin Neurosci 2003; 10: 74-78.

37. Lansberg, M.G.: Concurrent presentation of perimesencephalic subarachnoid hemorrhage and ischemic stroke. J Stroke Cerebrovasc Dis 2008; 17: 248-250.

38. Little, A., Garrett, M., Germain, R., et al.: Evaluation of patients with spontaneous subarachnoid hemorrhage and negative angiography. Neurosurgery 2007; 61: 1139-1150; discussion 1150-1131.

39. Loiseau, H., Castel, J., Stoïber, H.: Clinical, neuroradiologic and developmental aspects of idiopathic benign subarachnoid hemorrhage (subarachnoid hemorrhage of unknown cause). Retrospective study of 65 cases. Neurochirurgie 1989; 35: 222-228.

40. Martínez-Mañas, R., Ibáñez, G., Macho, J., Gastón, F., Ferrer, E.: A study of 234 patients with subarachnoid hemo- rrhage of aneurysmic and cryptogenic origin. Neurocirugia 2002; 13: 181-193; discussion 193-185.

41. Mathews, M., Brown, D., Brant-Zawadzki, M.: Perimesencephalic nonaneurysmal hemorrhage associated with vein of Galen stenosis. Neurology 2008; 70: 2410-2411.

42. Matsumaru, Y., Yanaka, K., Muroi, A., Sato, H., Kamezaki, T., Nose, T.: Significance of a small bulge on the basilar artery in patients with perimesencephalic nonaneurysmal subarachnoid hemorrhage. Report of two cases. J Neurosurg 2003; 98: 426-429.

43. Matsuyama, T., Okuchi, K., Seki, T., Higuchi, T., Murao, Y.: Perimesencephalic nonaneurysmal subarachnoid hemorrhage caused by physical exertion. Neurol Med Chir (Tokyo) 2006; 46: 277-281; discussion 281-272.

44. McLaughlin, N., Adada, B., Bojanowski, W.: Idiopathic subarachnoid hemorrhage: is the perimesencephalic distribution that benign? Neurochirurgie 2005; 51: 107-112.

45. Müller-Forell, W., Welschehold, S., Köhler, J., Schicketanz, K.: Subarachnoid hemorrhage without aneurysm. Radiologe 2002; 42: 871-879.

46. Muñoz-Sánchez, M., Cayuela-Domínguez, A., Murillo-Cabezas, F.: Improving the outcomes in spontaneous subarachnoid haemorrhage: the EHSA project. Rev Neurol 2009; 49: 399-404.

47. Park, S., Kwon, O., Kim, S., Oh, C., Han, M.: Premesencephalic subarachnoid hemorrhage: rupture of tiny aneurysms of the basilar artery perforator. Acta Neurochir (Wien) 2009; 151: 1639-1646.

48. Parkhutik, V., Lago, A., Tembl, J., Beltrán, A., Fuset, M.: Spontaneous subarachnoid haemorrhage: a study of 462 patients. Rev Neurol 2008; 46: 705-708.

49. Refai, D., Botros, J., Strom, R., Derdeyn, C., Sharma, A., Zipfel, G.: Spontaneous isolated convexity subarachnoid hemorrhage: presentation, radiological findings, differential diagnosis, and clinical course. J Neurosurg 2008; 109: 1034-1041.

50. Rinkel, G., Wijdicks, E., Vermeulen, M., Hageman, L., Tans, J., van Gijn, J.: Outcome in perimesencephalic (nonaneurysmal) subarachnoid hemorrhage: a follow-up study in 37 patients. Neurology 1990; 40: 1130-1132.

51. Rinkel, G., Wijdicks, E., Hasan, D., et al.: Outcome in patients with subarachnoid haemorrhage and negative angiography according to pattern of haemorrhage on computed tomography. Lancet 1991; 338: 964-968.

52. Rinkel, G.J., Wijdicks, E.F., Vermeulen, M., et al.: Nonaneurysmal perimesencephalic subarachnoid hemorrhage: CT and MR patterns that differ from aneurysmal rupture. AJNR Am J Neuroradiol 1991; 12: 829-834.

53. Ronne-Engstrom, E., Enblad, P., Gal, G., et al.: Patients with spontaneous subarachnoid haemorrhage - presentation of a 10-year hospital series. Br J Neurosurg 2009; 23: 499-506.

54. Rosengart, A.J., Schultheiss, K.E., Tolentino, J., Macdonald, R.L.: Prognostic factors for outcome in patients with aneurysmal subarachnoid hemorrhage. Stroke 2007; 38: 2315-2321. 
55. Ruigrok, Y., Rinkel, G., Buskens, E., Velthuis, B., van Gijn. J.: Perimesencephalic hemorrhage and CT angiography: A decision analysis. Stroke 2000; 31: 2976-2983.

56. Ruiz-Sandoval, J., Cantu, C., Chiquete, E., et al.: Aneurysmal subarachnoid hemorrhage in a Mexican multicenter registry of cerebrovascular disease: the RENAMEVASC study. J Stroke Cerebrovasc Dis 2009; 18: 48-55.

57. Salazar Benitez, J., Bravo Utrera, M., Hervas Garcia, M., Fernandez Fernandez, O.: Angiogram-negative subarachnoid hemorrhage. Should the procedure be repeated? Neurologia $1996 ; 11: 248-250$.

58. Sangra, M., Teasdale, E., Siddiqui, M., Lindsay, K.: Perimesencephalic nonaneurysmal subarachnoid hemorrhage caused by jugular venous occlusion: case report. Neurosurgery 2008; 63: E1202-1203; discussion E1203.

59. Schievink, W., Wijdicks, E.: Origin of pretruncal nonaneurysmal subarachnoid hemorrhage: ruptured vein, perforating artery, or intramural hematoma? Mayo Clin Proc 2000; 75: 1169-1173.

60. Schievink, W., Wijdicks, E., Spetzler, R.: Diffuse vasospasm after pretruncal nonaneurysmal subarachnoid hemorrhage. AJNR 2000; 21: 521-523.

61. Schwartz, T.H., Solomon, R.A.: Perimesencephalic nonaneurysmal subarachnoid hemorrhage: review of the literature. Neurosurgery 1996; 39: 433-440; discussion 440.

62. Schwartz, T., Farkas, J.: Quadrigeminal non-aneurysmal subarachnoid hemorrhage--a true variant of perimesencephalic subarachnoid hemorrhage. Case report. Clin Neurol Neurosurg 2003; 105: 95-98.

63. Shea, A., Reed, S., Curtis, L., Alexander, M., Villani, J., Schulman, K.: Characteristics of nontraumatic subarachnoid hemorrhage in the United States in 2003. Neurosurgery 2007; 61: 1131-1137; discussion 1137-1138.

64. Tatter, S., Buonanno, F., Ogilvy, C.: Acute lacunar stroke in association with angiogram-negative subarachnoid hemorrhage. Mechanistic implications of two cases. Stroke 1995; 26: 891-895.

65. Tatter, S.B., Crowell, R.M., Ogilvy, C.S.: Aneurysmal and microaneurysmal "angiogram-negative" subarachnoid hemorrhage. Neurosurgery 1995; 37: 48-55.

66. Teunissen, L., Rinkel, G., Algra, A., van Gijn, J.: Risk factors for subarachnoid hemorrhage: a systematic review. Stroke 1996; 27: 544-549.

67. Topcuoglu, M., Ogilvy, C., Carter, B., Buonanno, F., Koroshetz, W., Singhal, A.: Subarachnoid hemorrhage without evident cause on initial angiography studies: diagnostic yield of subsequent angiography and other neuroimaging tests. J Neurosurg 2003; 98: 1235-1240.

68. Van der Schaaf, I., Velthuis, B., Gouw, A., Rinkel, G.: Venous drainage in perimesencephalic hemorrhage. Stroke 2004: 35: 1614-1618.

69. van Dijk, E., Hupperts, R., van der Jagt, M., Bijvoet, H., Hasan, D.: Diagnosis of perimesencephalic nonaneurys- mal subarachnoid hemorrhage with computed tomography. J Stroke Cerebrovasc Dis 2001; 10: 247-251.

70. Van Gijn, J., Van Dongen, K., Vermeulen, M., Hijdra, A.: Perimesencephalic hemorrhage: a nonaneurysmal and benign form of subarachnoid hemorrhage. Neurology 1985; 35: 493-497.

71. Velthuis, B., Rinkel, G., Ramos, L., Witkamp, T., van Leeuwen, M.: Perimesencephalic hemorrhage. Exclusion of vertebrobasilar aneurysms with CT angiography. Stroke 1999; 30: 1103-1109.

72. Vermeer, S., Rinkel, G., Algra, A.: Circadian fluctuations in onset of subarachnoid hemorrhage. New data on aneurysmal and perimesencephalic hemorrhage and a systematic review. Stroke 1997; 28: 805-808.

73. Watanabe, A., Hirano, K., Kamada, M., Imamura, K., Ishii, N., Sekihara, Y., Suzuki, Y., Ishii, R.: Perimesencephalic nonaneurysmal subarachnoid haemorrhage and variations in the veins. Neuroradiology 2002; 44: 319-325.

74. White, J., Wijdicks, E., Cloft, H., Kallmes, D.: Vanishing aneurysm in pretruncal nonaneurysmal subarachnoid hemorrhage. Neurology 2008; 71: 1375-1377.

75. Whiting, J., Reavey-Cantwell, J., Velat, G., et al.: Clinical course of nontraumatic, nonaneurysmal subarachnoid hemorrhage: a single-institution experience. Neurosurg Focus 2009; 26: E21.

76. Wijdicks, E., Schievink, W., Miller, G.: Pretruncal nonaneurysmal subarachnoid hemorrhage. Mayo Clin Proc 1998; 73: 745-752.

77. Yamakawa, H., Ohe, N., Yano, H., Yoshimura, S., Iwama, T.: Venous drainage patterns in perimesencephalic nonaneurysmal subarachnoid hemorrhage. Clin Neurol Neurosurg 2008; 110: 587-591.

78. Zetterling, M., Hallberg, L., Ronne-Engström, E.: Early global brain oedema in relation to clinical admission parameters and outcome in patients with aneurysmal subarachnoid haemorrhage. Acta Neurochir (Wien) 2010; in press. May 22, Epub ahead of print.

79. Zhang, Y., Tanaka, T., Samuels, O., et al.: Poor outcomes in patients with angiographically negative subarachnoid hemorrhage. Neurosurgery 2006; 58: 405-406.

Sarabia, R; Lagares, A; Fernández-Alén, J.A.,; Arikan, F.; Vilalta, J.; Ibáñez, J.; Maillo, A.; Gabarros, A.; Domínguez, J.; Horcajadas, A.; Ballenilla, F.; Rodríguez-Boto, G.; Llacer, J.L.; Arrese, I.; de la Lama, A.; Santamarta, D.; Delgado, P.; Muñoz, M.F.: Idiopathic subarachnoid hemorrhage: a multicentre series of 220 patients. Neurocirugía 2010; 21: 441-451.

Corresponding author: Rosario Sarabia MD. Hospital Clínico Universitario. Neurosurgical Service. Avda. Ramón y Cajal s.n. 47005 Valladolid. Spain rosariosarabia@terra.es 